\title{
Steve Murphy, Baudelaire? Coupable
}

\section{Ida Merello}

\section{(2) OpenEdition}

\section{Journals}

\section{Edizione digitale}

URL: http://journals.openedition.org/studifrancesi/8990

DOI: 10.4000/studifrancesi.8990

ISSN: 2427-5856

\section{Editore}

Rosenberg \& Sellier

\section{Edizione cartacea}

Data di pubblicazione: 1 octobre 2008

Paginazione: 481

ISSN: 0039-2944

\section{Notizia bibliografica digitale}

Ida Merello, «Steve Murphy, Baudelaire? Coupable», Studi Francesi [Online], 155 (LII | II) | 2008, online dal 30 novembre 2015, consultato il 11 janvier 2021. URL: http://journals.openedition.org/studifrancesi/ 8990 ; DOI: https://doi.org/10.4000/studifrancesi.8990

\section{Questo documento è stato generato automaticamente il 11 janvier 2021.}

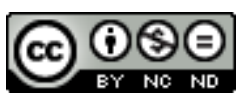

Studi Francesi è distribuita con Licenza Creative Commons Attribuzione - Non commerciale - Non opere derivate 4.0 Internazionale. 


\title{
Steve Murphy, Baudelaire? Coupable
}

\author{
Ida Merello
}

\section{NOTIZIA}

STEVE MURPHY, Baudelaire? Coupable, «Histoires littéraires», n. 31, juill-août-sept. 2007, pp. 7-24.

1 L'A. riprende la questione del processo per oscenità delle Fleurs, e ricorda come l'erotismo e la sovversione della raccolta fossero presi già in conto dai precedenti titoli immaginati, Les Limbes o Les Lesbiennes. Cita poi la nota di Baudelaire che giustificava la sezione della Révolte come rappresentazione della corruzione, distinguendo così tra l'io empirico e le diverse voci poetiche. Voci del cui pluralismo il poeta appare perfettamente cosciente, nel momento in cui conserva nell'ultima edizione quei componimenti ispirati all'utopia sociale che invece nella sua parabola umana ha abbandonato. Baudelaire conferma così la volontarietà della spersonalizzazione dell'io che già Friedrich indicava come caratteristica distintiva della sua opera. L'A. mostra però come Baudelaire resti comunque preoccupato di un rifiuto della propria opera da parte anche del futuro lettore borghese, e accenni al possibile carattere repulsivo dei suoi testi in un progetto di prefazione alla terza edizione. La sua strategia di difesa consiste, a livello testuale, in una "programmation d'effets", ossia in una fede in quei valori formali che Friedrich già aveva individuato come mezzi di salvazione, e a livello di dichiarazioni in una serie di negazioni che invece sottolineano gli elementi trasgressivi. L'A. ricorda infine la revisione del processo a Baudelaire nel 1946, conclusosi con una sua ascetizzazione del tutto mistificante. 